\title{
Traumatic tension pneumopericardium and amputation of the left main bronchus
}

\author{
Lech Krawczyk, Tomasz P. Byrczek, Agata Łuczyk, Bogusz D. Jagoda, Rafał Kazanowski, Michał J. Stasiowski \\ Department of Anesthesiology and Intensive Therapy, School of Medicine with the Division of Dentistry \\ in Zabrze, Medical University of Silesia in Katowice, St. Barbara's Memorial Hospital No. 5 Trauma Centre, \\ Sosnowiec, Poland
}

Kardiochirurgia i Torakochirurgia Polska 2017; 14 (1): 63-65

\begin{abstract}
A 27-year-old woman sustained a blunt chest trauma after a car accident. Computed tomography revealed tension pneumopericardium, bilateral pneumothorax, and a suspected rupture of the left main bronchus. Emergent pericardial needle aspiration was successfully performed. Bronchial amputation was confirmed by bronchofiberoscopy. Despite total detachment of the distal part of the bronchial tree, the ventilation of the left lung was maintained without air leakage by use of pleural drains. Bronchial obturation resulted from the injury, and was effectively treated by bronchoscopic sputum suction at the distal end of the bronchus. Finally, the patient underwent a left thoracotomy with an end-to-end bronchial anastomosis. The patient was discharged home on the $32^{\text {nd }}$ day after the trauma, and no complications were recorded during a 3-month follow-up period.
\end{abstract}

Key words: trauma, pneumopericardium, bronchial rupture.

\section{Introduction}

Pneumopericardium and tracheobronchial rupture are uncommon but potentially life-threatening complications of blunt chest trauma. Cardiac tamponade resulting from pneumopericardium occurs in $37 \%$ of trauma patients, and is associated with a $56 \%$ mortality rate; mechanical ventilation can be a significant contributor to the tension effect $[1,2]$. Aggressive volume resuscitation should be performed with emergent pericardial decompression by needle pericardiocentesis, percutaneous drainage, or a subxiphoid pericardial window via open thoracotomy or video-assisted thoracoscopy [3].

Despite increased clinical vigilance for tracheobronchial injuries, diagnosis can sometimes be delayed for weeks or months. With the exception of an acute course with dramatic air leakage, tracheobronchial ruptures are a chronic

\section{Streszczenie}

Kobieta 27-letnia uległa tępemu urazowi klatki piersiowej (ofiara wypadku komunikacyjnego). Na podstawie tomografii komputerowej rozpoznano prężną odmę osierdzia, obustronną odmę opłucnową oraz wysunięto podejrzenie uszkodzenia lewego oskrzela głównego. Doraźnie nakłuto igłą i odbarczono worek osierdziowy, uzyskując szybką poprawę hemodynamiczną. W bronchofiberoskopii potwierdzono amputację lewego oskrzela głównego. Mimo całkowicie oderwanej dystalnej części drzewa oskrzelowego wentylacja lewego płuca była zachowana przy jednoczesnym braku przecieku powietrza przez dreny opłucnowe. W trakcie leczenia doszło do obturacji oderwanego oskrzela wydzieliną, która została skutecznie usunięta w czasie kolejnej bronchofiberoskopii. Ostatecznie u chorej wykonano lewostronną torakotomię z zespoleniem oskrzela metodą koniec do końca. Pacjentka została wypisana do domu w 32. dobie i w dalszej, 3-miesięcznej obserwacji nie odnotowano żadnych istotnych powikłań.

Słowa kluczowe: uraz, odma osierdziowa, pęknięcie oskrzela.

process with persistent atelectasis, recurrent pneumothorax, or progressive bronchial constriction as well as accumulation of discharge.

Here, we present a case report of traumatic tension pneumopericardium and left main bronchial amputation that was successfully treated by pericardiocentesis and surgical bronchial repair.

\section{Case report}

A 27-year-old woman was involved in a frontal impact car collision with a pole; she was travelling in the front passenger seat and was not wearing a seat belt. Prolonged extrication was required. Intubation and initial fluid resuscitation were performed at the scene. On arrival at the Emergency Department at the Trauma Center in Sosnowiec, the patient was unconscious, her Glasgow

Address for correspondence: Lech Krawczyk MD, PhD, Assoc. Prof., Department of Anesthesiology and Intensive Therapy, St. Barbara's Memorial Hospital No. 5 Trauma Centre, 1 Medyków Square, 41-200 Sosnowiec, Poland, phone: +48 32368 23 41, e-mail: lechkrawczyk.icu@gmail.com Received: 16.02.2017, accepted: 22.02.2017. 


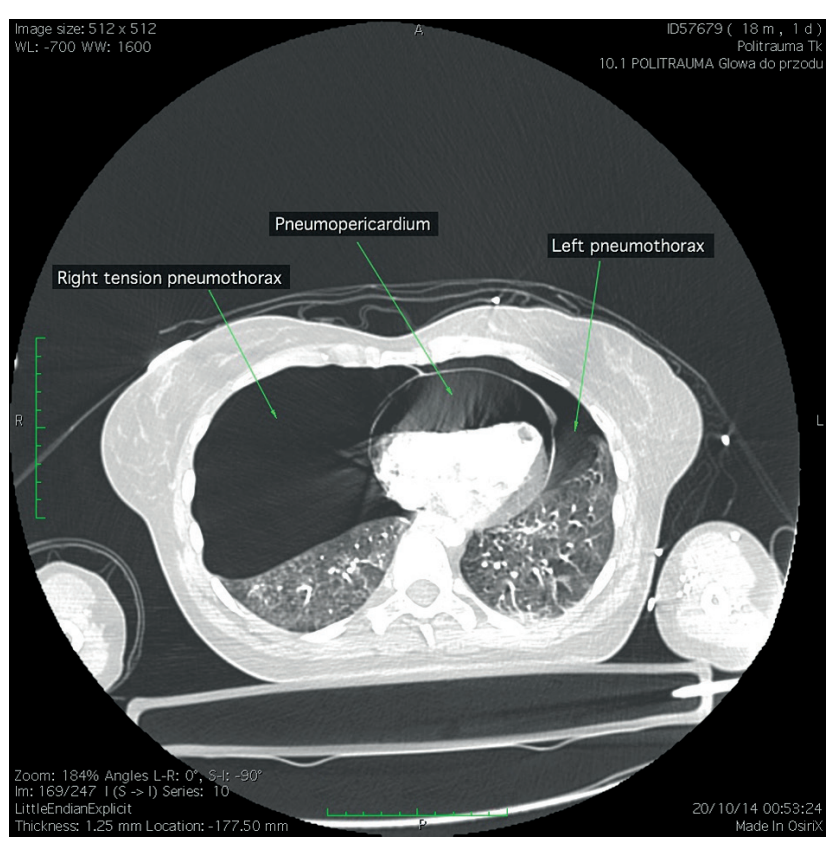

Fig. 1. Chest computed tomography obtained after admission of the patient to the emergency department showing cardiac tamponade due to tension pneumopericardium. Additionally, the right tension pneumothorax is shifting the heart to the left side

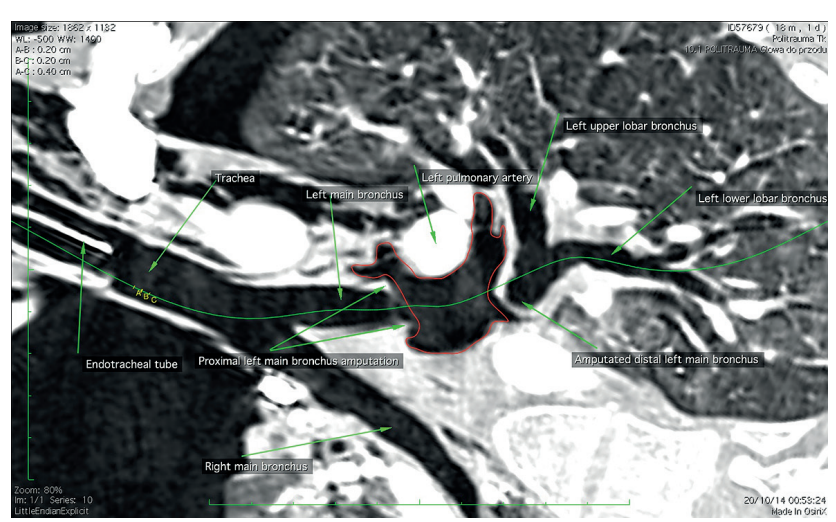

Fig. 2. The area circled in red refers to the artificial space bridging the detached ends of the left main bronchus

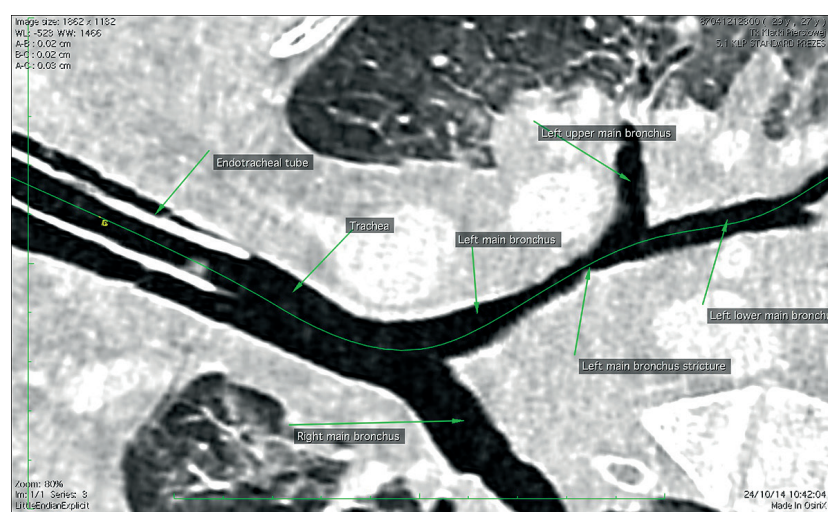

Fig. 3. Chest computed tomography after surgical repair. The constriction of the left bronchus can be seen at the surgical site
Coma Scale score was 7, and bag ventilation was in progress. Chest examination revealed bilateral crepitus, muffled heart sounds, and massive subcutaneous emphysema of the chest, neck, and head; this precluded assessment of the trachea and neck veins. Other injuries included pelvic, femoral, and ulnar fractures. Due to hemodynamic instability, fluid resuscitation was continued and catecholamine infusion was started. Bilateral needle pleurocentesis was immediately performed without significant air outflow. Total body computed tomography (CT) revealed multiple rib fractures, a bilateral pneumothorax, tension pneumopericardium with a 35-mm air layer, and pneumomediastinum with extensive subcutaneous emphysema (Fig. 1). Additionally, rupture of the left main bronchus was suspected. Emergent pericardial needle aspiration (about $90 \mathrm{ml}$ of air and bilateral pleural drainage) resulted in circulatory stabilization. Repeat chest $\mathrm{CT}$ revealed reduction of gas space in the pericardium to $12 \mathrm{~mm}$ without a tension effect and with gradual lung expansion. The patient was then transferred to the intensive care unit.

On the second post-trauma day, elective bronchoscopy revealed a complete transection of the left main bronchus (3-4 cm from the carina) with a slight constriction of the lumen caused by the emerging left pulmonary artery. This arterial vessel constituted part of the artificial canal (about $3 \mathrm{~cm}$ in length) created by other surrounding tissues (e.g., pleura, lung) and ended at the amputated distal parts of the bronchial tree (visible on deep exploration) (Fig. 2). On the next day, the patient's condition worsened; hypoxemia occurred and $100 \%$ oxygen ventilation was required. Additionally, the chest expansion on the left side diminished along with a decrease in breath sounds. There was still no air leakage through the pleural drains. Emergent bronchoscopy conducted through the artificial canal into the amputated part enabled the aspiration of bloody mucus from the obstructed lobar bronchi. The intervention resulted in significant improvement in ventilation, a rise in the $\mathrm{PaO}_{2} / \mathrm{FiO}_{2}$ ratio, and improved chest expansion and breath sounds on the left side. A few hours later, the patient underwent a left posterolateral thoracotomy with successful reconstruction of the bronchus.

For several days after the surgical procedure, multiple bronchofiberoscopies were required to clear the bronchial tree and evacuate the discharge. At the bronchial repair site, mucous membrane edema and bronchial constriction gradually regressed (Fig. 3). The patient was extubated on the $19^{\text {th }}$ day after the trauma; however, for a few days, proper oxygenation was maintained by noninvasive mechanical ventilation. The patient was discharged from the hospital 32 days after the trauma, and the 3-month follow-up yielded positive results.

\section{Discussion}

Tension pneumopericardium and tracheobronchial rupture are rare but life-threatening complications that can occur in patients with traumatic injuries. This case was unusual in a number of ways, i.e., the coexistence of these two rare conditions, and the creation of a patch 
from surrounding tissue that sealed the rupture site and maintained pulmonary function despite amputation. This is most likely the first description of bronchofiberoscopy of an amputated part of the bronchial tree.

Pneumopericardium has been recognized in many clinical settings; however, regardless of the etiology, progression to tamponade is observed in $37 \%$ of cases $[2,4]$.

Three main mechanisms of air penetration into the pericardium due to blunt chest trauma are known: a pleuropericardial connection in the presence of pneumothorax, tracking of pulmonary interstitial air along the pulmonary perivascular sheaths from ruptured alveoli to the pericardium, and direct tracheobronchial-pericardial communication [1]. In our case, all these pathways could have coexisted.

In the present case, single needle aspiration effectively reversed the tamponade. Considering the risk of tamponade recurrence, many authors recommend operative pericardial decompression via an open pericardial window or video-assisted thoracoscopy as a definitive treatment [1, 3, 5].

Based mostly on chest $\mathrm{CT}$, bronchial injury was suspected shortly after admission to the hospital. However, this is not usually the case due to lack of specific symptoms, associated injuries, and confusion during initial management of patients with severe trauma. According to an analysis of 265 cases of blunt tracheobronchial injuries, only $52 \%$ of patients with right-sided lesions and $14 \%$ of patients with leftsided lesions were diagnosed within the first $24 \mathrm{~h}$. Among the latter group, the median diagnosis and treatment times were 30 and 42 days, respectively [6]. This delay in recognition of left-sided injuries may be higher due to protection by adjacent structures of the left mediastinum. Additionally, a tight connective tissue sheath surrounding the main bronchi is described in the literature and can potentially seal the rupture site and allow adequate ventilation [7].

In our case, protective peribronchial coverage likely occurred, and along with fortunate positioning of the amputated bronchi, the gradual expansion of the "well-compliant" left lung and tight adherence of other mediastinal structures created space and conditions that preserved ventilation. The air-tightness of the canal was evidenced by lack of air leakage, and was even maintained during an episode of raised inspiratory pressure during severe obstruction of the amputated left bronchial tree with blood clot/discharge. This tightness was eventually confirmed by the thoracic surgeon during the bronchial repair.

The traditional strategy for management of tracheobronchial injuries has been surgery [8]; however, nonoperative treatment of such injuries has been recently proposed, especially for patients with post-intubation iatrogenic lesions, with good outcomes in carefully selected cases $[9,10]$. The criteria for such management include stable vital signs, small lacerations $(<2 \mathrm{~cm})$, a tube's cuff inflated distally to the site of the injury, efficient mechanical ventilation, evacuation of the air from the pleural cavity once a chest tube is placed, not increasing mediastinal emphysema, absence of esophageal injuries and an ongoing infection. Moreover, some studies support the role of con- servative treatment in selected patients with post-traumatic airway injuries as long as the abovementioned criteria are fulfilled and/or the patients present with a significantly high operative risk $[11,12]$. On the other hand, it should be underlined that the qualification for conservative management cannot definitely rule out the possibility of surgical treatment. These patients indeed should be strictly followed up in the ICU and they should be immediately referred for surgical treatment if airway obstruction and/or sepsis occur $[10,11]$. Nevertheless, a severely traumatized patient with injury, fulfilling the criteria for conservative treatment, located in the distal intrathoracic trachea and carina, seems to be a huge challenge. In cases of complete or almost complete bronchial transections surgery should be the treatment of choice [13].

\section{Conclusions}

The uniqueness of both traumatic complications, as well as other serious concurrent injuries and associated conditions, placed high demands on the medical staff during initial treatment of the patient. Only early diagnosis, based on a high index of suspicion, clinical symptoms, diagnostic imaging, bronchoscopy, and adequate surgical management, increased the chance of survival and led to positive treatment results.

\section{Disclosure}

Authors report no conflict of interest.

\section{References}

1. Capizzi PJ, Martin M, Bannon M. Tension pneumopericardium following blunt injury. J Trauma 1995; 39: 775-780.

2. Cummings RG, Wesley RLR, Adams DH, Lowe JE. Pneumopericardium resulting in cardiac tamponade. Ann Thorac Surg 1984; 37: 511-518.

3. Gould JC, Schurr MA. Tension pneumopericardium after blunt chest trauma. Ann Thorac Surg 2001; 72: 1728-1730.

4. Levin S, Maldonado I, Rehm C, Ross S, Weiss RL. Cardiac tamponade without pericardial effusion after blunt chest trauma. Am Heart J 1996; 131: 198-200.

5. Polhill JL, Sing RF. Traumatic tension pneumopericardium. J Trauma 2009; 66: 1261.

6. Kiser AC, O’Brien SM, Detterbeck FC. Blunt tracheobronchial injuries: treatment and outcomes. Ann Thorac Surg 2001; 71: 2059-2065.

7. Taskinen SO, Salo JA, Halttunen PE, Sovijärvi AR. Tracheobronchial rupture due to blunt chest trauma. Ann Thorac Surg 1989; 48: 846-849.

8. Rossbach MM, Johnson SB, Gomez MA, Sako EY, Miller OL, Calhoon JH. Management of major tracheobronchial injuries: a 28-year experience. Ann Thorac Surg 1998; 65: 182-186.

9. Koletsis E, Prokakis C, Baltayiannis N, Apostolakis E, Chatzimichalis A, Dougenis D. Surgical decision making in tracheobronchial injuries on the basis of clinical evidences and the injury's anatomical setting: a retrospective analysis. Injury 2012; 43: 1437-1441.

10. Carretta A, Melloni G, Bandiera A, Negri G, Voci C, Zannini P. Conservative and surgical treatment of acute posttraumatic tracheobronchial injuries. World J Surg 2011; 35: 2568-2574.

11. Gomez-Caro A, Moradiellos FJ, Diaz-Hellin V, Larrú E, Pérez JA, de Nicolás JL Role of conservative medical management of tracheobronchial injuries. J Trauma 2006; 61: 1426-1435.

12. Kuhne CA, Kaiser GM, Flohe S, Beiderlinden M, Kuehl H, Stavrou GA, Waydhas C, Lendemanns S, Paffrath T, Nast-Kolb D. Nonoperative management of tracheobronchial injuries in severely injured patients. Surg Today 2005; 35: 518-523.

13. Glazer ES, Meyerson SL. Delayed presentation and treatment of tracheo bronchial injuries due to blunt trauma. J Surg Educ 2008; 65: 302-308. 